\title{
WILL SURVIVING CONSTITUTIONALISM IN MOROCCO AND JORDAN WORK IN THE LONG RUN? A COMPARISON WITH THREE PAST AUTHORITARIAN REGIMES
}

\section{Francesco Biagi*}

\begin{abstract}
In the past three years, Morocco and Jordan have introduced political and constitutional reforms. Indeed, despite the fact that King Mohammed VI in Morocco and King Abdullah II in Jordan continue to hold near absolute powers, both the 2011 Moroccan Constitution and the constitutional amendments to the 1952 Jordan Constitution introduced some important democratic novelties. The impression is that Mohammed VI and Abdullah II gave rise to what can be defined as 'surviving constitutionalism': a constitutionalism whose main purpose is not to democratize the country, but to guarantee the regimes' own survival. We are therefore dealing with the paradox according to which constitutionalism - which should be aimed at limiting arbitrary power - is used as a means to maintain and strengthen authoritarian/semi-authoritarian regimes. This paper shows that the constitutional and political reforms carried out in these two countries were indeed primarily directed to appease people's discontent to ensure the regimes' stability and continuity. However, this paper also argues that it is far from certain that this strategy will work in the long run. A comparative analysis with other past authoritarian regimes (in particular Chile, Mexico and Egypt), shows that the constitutional institutions introduced in Morocco (e.g. the duty of the King to appoint the Head of Government from the party which wins the most seats in the elections to the House of Representatives, the introduction of concrete constitutional review, and the strengthening of judicial independence) and Jordan (e.g. the establishment of a Constitutional Court, judicial oversight of elections, and the abolition of the King's power to indefinitely postpone elections) should not be underestimated: they may become effective constraints on authoritarian power in the future. Thus, the 'surviving constitutionalism' that has served to appease the public's dissatisfaction in the short term may boomerang in the medium and long term.
\end{abstract}

\section{Keywords}

Constitutionalism, Transition to Democracy, Authoritarian Regimes

\footnotetext{
* Post-doctoral Research Fellow in Comparative Public Law at the University of Bologna; Researcher at the Center for Constitutional Studies and Democratic Development, Johns Hopkins University SAIS Europe in Bologna.
}

Copyright $\odot$ the Author(s).

This work is licensed under a Creative Commons Attribution-NonCommercial-NoDerivs 3.0 License. 


\section{Introduction}

In the past few years, Middle Eastern and North African (MENA) countries have experienced profound transformations, especially on social, constitutional and political fronts. Indeed, the phenomenon known as the 'Arab Spring' began on 17 December 2010, when a young street vendor named Mohamed Bouazizi lit himself on fire in the town of Sidi Bouzid, in Tunisia, as a sign of protest against the regime of Ben Ali for the nation's high unemployment rate, rampant corruption, and more generally for the lack of fundamental freedoms and rights. This episode, and especially Bouazizi's eventual death on 4 January 2011, gave rise to mass protest demonstrations in the country, and after a few days President Ben Ali, who had ruled over the people for 23 years, was forced to flee Tunisia. What happened in this country acted as a catalyst for the rest of the Arab world: protests, demonstrations and in some cases even revolutions took place in a number of MENA countries.

The consequences of these events are impressive. First and foremost, it is important to stress that four long-lasting dictators were overthrown: Ben Ali in Tunisia, Qaddafi in Libya, Mubarak in Egypt and Saleh in Yemen. Another relevant characteristic common to many of the countries involved in the Arab uprisings was the rise to power of Islamist movements. For example, the Justice and Development Party won the November 2011 parliamentary elections in Morocco, Ennhadha came out as the party with a relative majority in Tunisia and the Muslim Brotherhood (through its Freedom and Justice Party) won the parliamentary and presidential elections in Egypt.

Furthermore, many of these countries decided to mark a discontinuity with the past by adopting a new constitution or making constitutional amendments. Morocco was the first country involved in the Arab upheavals to adopt a new constitution, in July 2011, followed by Egypt, which adopted two constitutions in the span of one year. The first came into force in December 2012; however, on 8 July 2013, following President Mohamed Morsi's removal from office, Egypt's interim president, Adly Mansour, issued a new constitutional declaration that suspended the 2012 Constitution and laid out a process for amending it. The revised Constitution came into force in January 2014. In the same month, after more than two years of debates in the Constituent Assembly, the new Tunisian Constitution was adopted. In Jordan, King Abdullah II decided to introduce a number of changes to the 1952 Constitution and to partially amend the electoral law. This 'wave of constitutionalism' in the Arab world does not seem to be over yet. In Yemen, for example, a constitution-drafting committee was formed some 
months ago. Moreover, notwithstanding the huge difficulties that Libya is facing, even that country has started a constitution-making process.

In this paper, I will limit the scope of my analysis to Morocco and Jordan, and I will show that the constitutional and political reforms carried out in these two countries mainly responded to the need to appease people's discontent so as to ensure the regimes' stability and continuity. I will point out that King Mohammed VI in Morocco and King Abdullah II in Jordan gave rise to what can be described as 'surviving constitutionalism': 1 their main purpose was not to democratise their country, but to guarantee their own survival. I will then argue that it is not certain that this strategy will work in the long run. In fact, a comparative analysis with other past authoritarian regimes (i.e., Chile, Egypt and Mexico) shows that the strengthening of democratic procedures and institutions introduced in the constitutions of Morocco and Jordan are not necessarily only 'cosmetic', but they may become effective constraints of authoritarian power in the future.

Accordingly, this paper proceeds in four sections. First, I point out the reasons the Arab monarchies have so far survived the Arab uprisings. Second, I illustrate the main novelties introduced in the 2011 Constitution of Morocco and in the amendments to the 1952 Constitution of Jordan, and I show that Mohammed VI and Abdullah II used these reforms as instruments of survival. In the third section, I discuss the cases of Chile under Pinochet, Egypt under Mubarak and Mexico during the era of a single hegemonic party in order to stress that an autocratic regime can be bound by a constitution of its own making. Finally, I draw some concluding remarks.

\section{The Resistance of Arab Monarchies to the Uprisings}

Sean L. Yom and F. Gregory Gause III have rightly stressed that the 'Arab Spring' might just as well be called the 'Arab Republics' Spring.' As a matter of fact, while several long-lasting authoritarian presidents in the MENA region have been overthrown, Arab monarchs have so far survived the Arab uprisings.

\footnotetext{
${ }^{1}$ See also J O Frosini \& F Biagi, 'Transitions from Authoritarian Rule following the Arab Uprisings: A Matter of Variables', in J O Frosini \& F Biagi (eds), Political and Constitutional Transitions in North Africa: Actors and Factors (2014).

2 S L Yom \& F G Gause III, 'Resilient Royals: How Arab Monarchies Hang On' (2012) 23 Journal of Democracy 74,74 .
} 
Besides mere repression, the literature ${ }^{3}$ has identified many other factors that explain how the eight Arab monarchies (Morocco, Jordan, Kuwait, Saudi Arabia, Oman, Qatar, the United Arab Emirates [UAE] and Bahrain) have managed to resist the wind of change that has been blowing in the Arab world since December 2010.

First of all, one should not forget the high degree of religious or tribal legitimacy enjoyed by Arab monarchs. The Alaouite crown of Morocco and the Hashemite House of Jordan claim direct descent from the Prophet Mohammed. King Abdullah of Saudi Arabia is often referred to as 'Custodian of the Two Holy Mosques', Mecca and Medina. ${ }^{4}$ The royal families in Bahrain, Kuwait, Oman, Qatar, Saudi Arabia and the UAE command authority and respect among the tribal confederations in their societies.

Second, Arab kings and emirs are often considered the effective guarantors of social and political stability. In Morocco, one of the main reasons Mohammed VI was not called into question is because the people think that without the king and his 'unifying role', the country would be ungovernable. In Jordan, the monarchy serves as a 'security blanket for all Jordanians regardless of their origins, providing protection for the country's various ethnic groups.' ${ }^{5}$ Furthermore, 'in times of unrest, crowds are more likely to protest for legislative change than for the abandonment of the monarchy' ${ }^{6}$

Third, Arab monarchs do not 'dirty their hands' in everyday politics. This gives them a twofold advantage: first, when things go wrong, they tend to lay all the blame on the politicians; second, when they are put under significant pressure by the population, they can initiate political, economic and constitutional changes and appear as the country's real reformers. As we will see, this is precisely the strategy followed by Mohammed VI in Morocco and Abdullah II in Jordan.

Fourth, access to oil rents continues to be a strategic means for 'petro-

\footnotetext{
3 Ibid; R Brynen, P W Moore, B F Salloukh \& M-J Zahar, Beyond the Arab Spring: Authoritarianism \& Democratization in the Arab World (2012) 173 ff.; M Ottaway \& M Muasher, 'Arab Monarchies: Change for Reform, Yet Unmet' (December 2011) The Carnegie Papers <http://carnegieendowment.org/files/arab_monarchies1.pdf> [accessed 11 April 2014]; L Noueihed \& A Warren, The Battle for the Arab Spring: Revolution, Counter-revolution and the Making of a New Era (2012) 245 ff.; A Keyman, 'The Resilience of Arab Spring Monarchies' (April 2012) e-International Relations <http://www.e-ir.info/2012/04/02/the-resilience-of-arab-monarchiesin-the-arab-spring/\#_ftnl> [accessed 11 April 2014].

4 Keyman, above n 3.

5 Ottaway \& Muasher, above n 3, 9.

6 J A Goldstone, 'Understanding the Revolutions of 2011’ (May/June 2011) 90 Foreign Affairs 8, 13.
} 
monarchies' to prevent dissent and to calm protests. ${ }^{7}$ In fact, in order to appease public dissatisfaction, oil-rich monarchies have used the revenues deriving from oil reserves to give state employees pay raises and welfare payouts, and to create jobs, loan benefits and costly price subsidies. It should be noted that 'oil rents easily recirculate across borders in the form of aid,', and therefore even non-oil countries (such as Jordan and Morocco) have benefitted through the economic assistance of wealthier monarchies, such as those in Saudi Arabia, Kuwait, Qatar and the UAE.

Fifth, Arab monarchs can count on 'foreign patrons': ${ }^{9}$ the Unites States in Jordan and in the Gulf monarchies, and France in Morocco are probably the most evident examples. These close relations were of fundamental importance even during the Arab upheavals, in order to constrain 'Western calls for change.' ${ }^{\text {' In }}$ Bahrain, given the presence of the US Fifth Fleet, the United States' criticism of the gross violations of human rights by the police during the 2011 February protests was very limited. In much the same way, former French President Nicolas Sarkozy did not call for regime change in Morocco; on the contrary, he defined the reform process carried out by Mohammed VI as 'exemplary'.

As far as external involvement is concerned, the monarchies' survival was also guaranteed through the military intervention of the Gulf Cooperation Council (GCC). This happened in Bahrain, which is the only Arab monarchy to have experienced large-scale protest demonstrations similar to those that took place in the republics. The GCC's action was crucial to calm the situation.

\section{Surviving Constitutionalism}

Despite the fact that all the Arab monarchies have managed to resist to the wind of change, one cannot deny the fact that the Arab upheavals have produced some significant political and constitutional changes. Of course, a distinction should be drawn between the Gulf monarchies, on one hand, and Jordan and Morocco,

\footnotetext{
7 See S A Yetiv, 'Oil, Saudi Arabia, and the Spring that Has not Come', in M L Haas \& D W Lesch (eds), The Arab Spring: Change and Resistance in the Middle East (2013) 97, 97 ff. It should be noted, however, that oil rents play a key role not only in the monarchies, but also in the republics, such as in Algeria.

8 Yom \& Gause III, above n 2, 83.

9 Ibid, 84.

${ }^{10}$ Brynen, Moore, Salloukh \& Zahar, above n 3, 187.

${ }^{11}$ See <http://www.lemonde.fr/afrique/article/2011/06/18/la-france-salue-les-reformesannoncees-par-le-roi-du-maroc_1538011_3212.html> [accessed 11 April 2014].
} 
on the other. Indeed, if the former managed to preserve the status quo and were forced to introduce only extremely limited changes, ${ }^{12}$ the latter tried to compensate for a lack of oil reserves with political and constitutional reforms. In the following paragraphs I discuss the major novelties introduced in the 2011 Constitution of Morocco and in the amendments to the 1952 Constitution of Jordan; I show that both Mohammed VI and Abdullah II opted for these reforms so as to calm down the protest demonstrations and guarantee the stability and the continuity of their regimes. In other words, constitutionalism represented for both kings an instrument of survival, and for this very reason, one can refer to it as 'surviving constitutionalism'.

\subsection{The 2011 Constitution of Morocco}

The first protest demonstrations broke out in Morocco after 20 February 2011 - the date from which the eponymous 'Mouvement du 20 Février' took its name. This movement, largely composed of young people, specifically denounced the systematic and endemic corruption, and the high cost of basic products alongside low wages and increasing poverty. It also called for greater social justice, free access to health care, greater employment opportunities and the right to housing. Young Moroccans also hoped for the achievement of profound and radical constitutional and political reforms, the construction of a state based on the rule of law, and a free and independent legal system in order to enable the country to become a parliamentary monarchy. ${ }^{13}$

The regime has been able to keep protest movements under control mainly due to the fact that it responded quickly to the requests being made. Indeed, on 9 March 2011 - less than three weeks after the first demonstrations - the king announced a far-reaching reform of the Constitution, which included some of the protestors' demands. Thus, Mohammed VI managed to turn the element of time to his advantage, catching the demonstrators off balance.

The new 2011 Constitution - which was adopted in less than four months - was 'granted' by the king, and did not result from a democratically elected Constituent Assembly. Indeed, the entire constituent process was driven

${ }^{12}$ In Saudi Arabia, for example, the king announced that women will be allowed to vote and run for office in the next municipal elections (2015); in Oman, the powers of the Shura Council were strengthened; in the UAE, the electorate for the Federal National Council was expanded (see Brynen, Moore, Salloukh \& Zahar, above n 3, 173 ff; Ottaway \& Muasher, above n 3, 14 ff).

${ }^{13}$ I Fernández Molina, 'The Monarchy vs. the 20 February Movement: Who Holds the Reins of Political Change in Morocco?' (2011) 16 Mediterranean Politics 435, 436-7. 
by Mohammed VI: ${ }^{14}$ it was he who decided to replace the previous (1996) Constitution, to identify in his speech on 9 March 2011 the 'key elements' on which that reform was to be based, to appoint the members of the Commission on Constitutional Reform (which had the task of drafting the new Constitution), and finally to grant his approval to the draft presented to him by the president of the Commission. In other words, he had the first and the last word. Moreover, considering that the consultation - held on 1 July 2011, through which the population ratified the new Constitution - was much more like an authoritarian plebiscite than a democratic referendum, it is evident that the 2011 Constitution represents another 'octroyée' Constitution in Moroccan history. ${ }^{15}$

The new Constitution both breaks from and maintains continuity with the previous one. In fact, although it introduced some relevant democratic novelties in relation, inter alia, to the protection of fundamental rights and freedoms, the horizontal separation of powers, and territorial organisation, it continues to grant the king near absolute powers.

As far as discontinuity is concerned, one must first underline that the new Constitution guarantees greater independence and autonomy to the judiciary. The latter has been elevated from a mere 'authority' (as defined under the 1996 Constitution) to the status of a full-blown branch of the state.

Its independence is guaranteed principally through the Higher Council of the Judicial Power, which replaced the High Council of Magistracy and acquired expanded functions. This body is still chaired by the king; however, under the new Constitution, the executive president is not the minister of justice (as provided under the 1996 Constitution) but is the first president of the Court of Cassation, thus making this body more independent.

The 2011 Constitution also introduced significant novelties in the field of constitutional adjudication. Indeed, in addition to ex ante review (already provided under the previous Constitution), the new Constitution allows for concrete constitutional review. In fact, Article 133 states, 'the Constitutional Court shall have competence to look into an exception of unconstitutionality raised in the course of a trial, when one of the parties argues that the law

\footnotetext{
${ }^{14}$ For a more detailed description of the Moroccan constituent process, see F Biagi, 'The 2011 Constitutional Reform in Morocco: More Flaws than Merits' (2014) 7 Jean Monnet Occasional Papers 6 ff., <http://www.um.edu.mt/europeanstudies/jmceu-med/papers> [accessed 11 April 2014]; see also F Biagi, "The Pilot of Limited Change. Mohammed VI and the Transition in Morocco', in Frosini \& Biagi, above $n 1$.

${ }^{15}$ Before the 2011 Constitution, Morocco had adopted five constitutions (in 1962, 1970, 1972, 1992 and 1996), and all of them can be considered 'octroyée' constitutions.
} 
on which depends the outcome of a trial undermines the rights and freedoms guaranteed by the Constitution'. The introduction of such ex post review thus appears extremely important in enabling the Court to reinforce its position as a counter-majoritarian body and may thus contribute to the process of democratisation more effectively than in the past.

Furthermore, while under the previous Constitution the prime minister was appointed at the discretion of the king, the 2011 Constitution states that the king appoints the head of government from the party that wins the most seats in the elections to the House of Representatives, and with a view to their results. This practice had already been followed on two occasions (following the 1997 and 2007 elections), although since it had no constitutional status, it could be disregarded at any time, as occurred following the 2002 elections. This will evidently place a significant limit on the king's powers, who will now be unable to appoint a head of government without reference to election results: it will therefore de facto be the people who choose the head of the executive.

It is also important to mention that the new Constitution declared the supremacy of international convention over domestic laws, and that national legislation must consequently be brought into line with the former. ${ }^{16}$

On the other hand, though, continuity with the past is still evident. First and foremost, despite what is stated in Article 1 of the Constitution, ${ }^{17}$ Morocco did not turn into a parliamentary monarchy based on the British or the Spanish model, where 'the King reigns but does not govern'. Indeed, the sovereign continues to be the key figure in determining political direction and adopting decisions of strategic importance for the country. First of all, the king continues to chair the Council of Ministers, the body that resolves matters of decisive interest for the state. Moreover, after consultation with the head of government, the king can dismiss ministers (Article 47) and has the power to dissolve the houses of parliament (after consultation with the president of the Constitutional Court and after informing the presidents of the two houses of parliament and the head of government) (Article 96). The sovereign also continues in his role as president

${ }^{16}$ It should be pointed out that the Constitution enshrines the supremacy of international conventions, but 'within the framework of the provisions of the Constitution, the laws of the Kingdom, and respect for its immutable national identity' (emphasis added). It is evident that the reference made by the Constitution pertains to the Islamic religion. It remains to be seen how judges will interpret this provision (on this point, see N Bernoussi, 'La Constitution de 2011 et le juge constitutionnel', in Centre d'Études Internationales (eds.), La Constitution marocaine de 2011: Analyses et commentaries (2012) 207, 225-6.

${ }^{17}$ Article 1 defines the monarchy not only as 'constitutional', 'democratic' and 'social', but also as 'parliamentary'. 
of the Higher Council of the Judicial Power (Article 56), supreme commander of the Royal Armed Forces (Article 53), and is also required to chair a new national security body, namely the Supreme Security Council.

Although Article 19 of the previous constitutions (which granted the king temporal and spiritual powers) has been 'split' into Articles 41 and 42, the sovereign continues to be both the head of state, the supreme representative of the nation, and the 'Amir Al Mouminine' - that is, the 'Commander of the Faithful'. From a symbolic point of view, the reform of the old Article 19 is a true revolution. For the first time in 50 years, the most important provision of the Moroccan Constitution has been changed, thus losing its 'sacredness'. However, it is far from certain that this 'split' will bring about significant novelties from a practical point of view. $^{18}$

The Constitution specifies that the sovereign shall exercise his powers through royal decrees (dahirs), which must be countersigned by the head of government. It should be stressed that whilst the dahirs that do not require countersignature by the head of government are now the exception, they do relate to matters of particular importance: in addition to the appointment of the head of government (Article 47), they cover the religious prerogatives inherent in the institution of the Commandership of the Faithful (Article 41), the appointment of the ten members of the Regency Council (Article 44), the dissolution of parliament (Article 51), the approval of appointments of magistrates by the Higher Council of the Judicial Power (Article 57), the proclamation of a state of emergency (Article 59), the appointment of half of the members of the Constitutional Court (Article 130), and the presentation of proposed constitutional amendments for referendum (Article 174). ${ }^{19}$

The strategy followed by Mohammed VI is clear. On one hand, the Moroccan monarch decided to adopt a new Constitution containing some important democratic novelties in order to appease public dissatisfaction and thus calm protests. On the other hand, he did not renounce most of his key powers and thus remained 'the master of the political game. ${ }^{20}$

\footnotetext{
${ }^{18}$ See D Melloni, 'Le nouvel ordre constitutionnel marocain: de la 'monarchie gouvernante' à la 'monarchie parlementaire'?', in Centre d'Études Internationales (eds), above n 16, 40.

${ }^{19}$ For a more detailed commentary on the new Constitution, see Centre d'Études Internationales (eds), above n 16; International IDEA, The 2011 Moroccan Constitution: A Critical Analysis (2012); A Bouachik, M Degoffe \& C Saint-Prot (eds), 'La Constitution marocaine de 2011: Lectures croisées' 77 Publications de la Revue marocaine d'administration locale et de développement, Série 'Thèmes actuels' (2012).

${ }^{20}$ A Tourabi, 'Constitutional Reform in Morocco: Reform in Times of Revolution' (2011)
} 


\subsection{The Amendments to the 1952 Constitution of Jordan}

Although the first demonstrations that can be linked to the Arab upheavals occurred in January 2011, it should be stressed that people in Jordan 'began taking to the street long before the first protests in Tunisia heralded the beginning of the Arab Spring. ${ }^{21}$ The uprisings that took place in the neighbouring countries simply made the lack of trust toward the regime even stronger. The demonstrations continued in February and reached their peak on March 24 and 25. The protesters - composed mainly of representatives of the Muslim Brotherhood, trade unions, non-Islamist opposition parties, and liberal youth activists - called for economic and political changes. They protested against rising food and fuel prices, inflation, unemployment and rampant corruption, and they sought a strengthening of the representative institutions (e.g., selection of the prime minister by the Chamber of Deputies, popular election of the upper house, reform of the electoral law), and ultimately transition to a parliamentary monarchy. Protesters' demands focused on 'changes within the regime rather than on regime change. 22

Similar to Mohammed VI in Morocco, Abdullah II played a crucial role in the reform process. Indeed, besides appointing four different prime ministers in the space of three years, ${ }^{23}$ in spring 2011 the monarch appointed two committees: the National Dialogue Committee to propose changes to the voting system, and the Royal Committee on Constitutional Amendments to propose reforms to the 1952 Constitution. The packet of constitutional reforms was adopted in September 2011, while, after months of bitter debate, in June 2012 the Parliament passed the new electoral law, which partially amended the 'single non-transferable vote' system in place since 1993.

Electoral legislation is an extremely sensitive issue in Jordan. First, one must consider that most of the members of the House of the Representatives are not affiliated with a party. This is due not only to historical reasons (between 1957 and 1992, political parties were illegal), but also to the electoral law. Indeed, the latter introduced an electoral system that allowed citizens 'to choose only one candidate

<http://www.arab-reform.net/sites/default/files/Morocco_EN.pdf> [accessed 11 April 2014].

${ }^{21}$ H A Barari \& C A Satkowski, 'The Arab Spring: The Case of Jordan' (2012) 3 Ortadoğu Etütleri 41, 48-9.

${ }^{22}$ Ottaway \& Muasher, above n 3, 9 (emphasis added).

${ }^{23}$ Marouf al-Bakhit in February 2011, Awn Shawkat Al-Khasawneh in October 2011, Fayez al-Tarawneh in May 2012, and Abdullah Ensour in October 2012; the latter was reappointed prime minister following the January 2013 parliamentary elections. 
even though several are elected from each district'. ${ }^{24}$ This system favoured tribal elites while disadvantaging the formation and development of political parties. In those parts of the country where tribal culture dominates, people tend to vote for those candidates affiliated with their tribe or family. ${ }^{25}$

The reform of the electoral law has met the demands of the opposition only in a very limited manner. The number of seats in the House of the Representatives was increased from 120 to 150 , and the quota reserved to women was increased from 12 to 15 seats. Of those 150 seats, only 27 (that is, 18\%) are now assigned through the new proportional national-list system; the rest are still allocated in accordance with the previous 'single non-transferable vote' system. Thus, it comes as no surprise that the results of the January 2013 parliamentary elections showed that the great majority of the elected are still the king's 'loyalists. ${ }^{26} \mathrm{~A}$ real reform of the electoral law therefore represents a condicio sine qua non for a transition to a democratic form of government.

The constitutional reforms were much more limited compared to Morocco's. Significantly, Chapter 4, Section I of the Constitution - devoted to 'The King and His Prerogatives' - has been left intact. This means that the monarch continues to hold executive power, able to appoint the prime minister and the senate, and dissolve both houses of the parliament. Moreover, he ratifies and promulgates the laws, and orders the enactment of the regulations necessary for their implementation. His veto power can only be overridden by a two-thirds vote of both houses. He is the 'Supreme Commander' of the armed forces, declares war, approves amendments to the Constitution and appoints and dismisses judges.

Having said that, the 2011 reform of the Constitution should not be underestimated. Indeed, the constitutional amendments include the prohibition of any form of torture and a partial enhancement of fundamental rights. Furthermore, judicial independence was slightly strengthened, and the government's power to issue temporary laws when parliament is not in session was partially limited.

Two other significant novelties refer to the organisation and oversight of elections, and to constitutional adjudication. As far as elections are concerned, it should be noted that the king has lost the power to indefinitely postpone elections, and that an independent electoral commission has replaced the Ministry of Interior in organising elections. The new commission has the task of supervising and administering the parliamentary electoral process (and any other elections

\footnotetext{
${ }^{24}$ Ottaway \& Muasher, above n 3, 10.

${ }^{25}$ See <http://www.europeanforum.net/country/jordan> [accessed 11 April 2014].

${ }^{26}$ On the results of these elections, see S L Yom, 'Jordan: The Ruse of Reform' (2013) 24 Journal of Democracy 127, 135.
} 
decided by the Council of Ministers) at all stages. Moreover, the House of the Representatives has lost the power to determine the validity of the election of its members. Now this task has been assigned to the Court of Appeal, whose decisions are final and not subject to any challenge. The set-up of an electoral commission combined with judicial oversight of the elections has undoubtedly established the conditions to make the elections more free and fair.

With regard to constitutional adjudication, it is important to stress that despite recurrent calls for the creation of a similar body, ${ }^{27}$ Jordan did not have a constitutional court. This demand was finally addressed in 2011. Despite some concerns regarding its independence (for example, all the justices are appointed by the king), the establishment of the Constitutional Court must be welcomed. This new body has the power to check the constitutionality of laws and regulations, as well as to interpret the provisions of the Constitution. Claims before the Court can be lodged by the senate, the Chamber of Deputies and the Council of Ministries. Interestingly enough, the reform of the Constitution has also introduced concrete constitutional review. ${ }^{28}$

Unlike Morocco, where the process of constitutional implementation is proceeding at a rather slow pace, in Jordan both the Electoral Commission and the Constitutional Court have already been established. The former supervised the electoral process for the first time during the January 2013 elections.

King Abdullah II's strategy very much resembled the one followed by Mohammed VI. Indeed, the Jordanian monarch decided to introduce constitutional and electoral reforms in order to meet - at least partially - protesters' demands. At the same time, however, almost all his powers remained in his hands.

\section{Constitutionalism in Non-Democratic Regimes}

In the previous paragraphs, I showed that Mohammed VI and Abdullah II gave rise to surviving constitutionalism: indeed, both the 2011 Moroccan Constitution and the amendments to the Jordanian Constitution mainly responded to the

\footnotetext{
${ }^{27}$ See M L Burgis, 'Judicial Reform and the Possibility of Democratic Rule in Jordan: A Policy Perspective on Judicial Independence' (2007) 21 Arab L Quarterly 135, 162-3; M Abu-Karaki, 'Democracy \& Judicial Controlling in Jordan: A Constitutional Study' (2011) $4 \mathrm{~J}$ of Politics and $L 180,180 \mathrm{ff}$.

28 'In pending cases, any party to the lawsuit may argue that a law is not in conformity with the Constitution. In case the relevant court finds that the plea has merit, it must refer the matter to the court specified by the law for the purposes of examining the referral of such to the Constitutional Court' (Art 60).
} 
need to appease people's discontent so as to ensure the regimes' stability and continuity. The two kings allowed constitutional reforms to take place as long as their key powers and prerogatives were not questioned: their main purpose was not to democratise the country, but to guarantee their own survival. We are therefore dealing with the paradox according to which constitutionalism - which should be aimed at limiting arbitrary power - is used as an instrument to maintain and strengthen authoritarian/semi-authoritarian rules.

It is accepted that Mohammed VI and Abdullah II have so far achieved their aim: both monarchies continue to be executive monarchies, and the countries have remained authoritarian/semi-authoritarian regimes. ${ }^{29}$ Initially, one may be tempted to think that the two kings can sleep easy. The novelties introduced in the Moroccan and Jordanian constitutions do not seem to represent (at least up to the present time) a threat to the monarchies. Indeed, constitutions in authoritarian/semi-authoritarian contexts are often considered 'paper tigers'. This assumption is true in most cases, but not always. Indeed, in the following paragraphs, on the basis of a comparative analysis with other past non-democratic regimes, I show that the strategy followed by Mohammed VI and Abdullah II may not work in the long run, since the strengthening of democratic procedures and institutions are not necessarily only 'cosmetic', but may become effective constraints of autocratic power in the future. The non-democratic regimes I will examine are Chile under Pinochet, Egypt under Mubarak, and Mexico during the era of a single hegemonic party (the PRI).

\subsection{The Case of Chile: The Role of the Tribunal Constitucional}

It is well known that from 11 September 1973 to 11 March 1990, Chile was governed by the authoritarian regime of General Augusto Pinochet. The case of Chile is extremely interesting because it shows that even an authoritarian regime can be bound by a constitution of its own making. Robert Barros pointed out that in 1980, Pinochet's regime 'introduced and sustained a constitution which set into operation institutions that limited the dictatorship's power and prevented it from unilaterally determining the outcome of the October 5, 1988 plebiscite which triggered the transition to democracy in 1990,30 It is important to stress that

\footnotetext{
${ }^{29}$ It is important to stress that according to the 2014 Freedom House Report on 'Freedom in the World', Morocco is considered a 'partially free' country, and Jordan a 'not free' country. See <http://freedomhouse.org/sites/default/files/FIW2014\%20Booklet.pdf> [accessed 11 April 2014].

${ }^{30}$ R Barros, Constitutionalism and Dictatorship: Pinochet, the Junta and the 1980 Constitution (2002) 1. The plebiscite was on whether President Augusto Pinochet should remain in office for a further
} 
the 1980 Constitution was not aimed at perpetuating the regime, but at providing an 'orderly transition' 31 once the military left power. Indeed, the institutional limits established by this Constitution were mainly designed to 'bind others, to hold future civilian actors to the terms of the military's constitution., ${ }^{32}$ In practice, however, what happened was that these institutions strongly limited the military dictatorship itself.

One of the institutions that most constrained Pinochet's regime was the Constitutional Court (Tribunal Constitucional). This body carried out, inter alia, mandatory, preventive constitutional review of organic constitutional law and laws interpreting the constitution, and it settled any constitutional disputes that arose in the course of processing bills, constitutional reform proposals or treaties requiring congressional approval. The Court was composed of seven members: three of them were elected by the Supreme Court, one by the president of the republic, one by the junta and two by the National Security Council. Thus, the majority of the membership had been selected by the military government.

Unlike the judiciary - which 'never sought to challenge the undemocratic, illiberal and antilegal policies of the military government ${ }^{33}$ - the Constitutional Court, since its very first judgment, ${ }^{34}$ proved to be anything but the regime's ally. In particular, the Tribunal played a fundamental role in determining the legal and institutional framework of the 1988 presidential plebiscite. On 24 September $1985{ }^{35}$ the Constitutional Court issued a landmark decision that required the Electoral Court (Tribunal Calificador de Elecciones) to be established for the plebiscite. In a narrow 4 to 3 vote, the majority of the Constitutional Court, by opting for a systematic interpretation of the constitution rather than a literal interpretation, stated that the Electoral Court needed to be operative for the plebiscite so as to oversee the regularity of the vote. According to the Tribunal Constitucional:

\footnotetext{
eight years.

${ }^{31}$ Z Elkins, T Ginsburg \& J Melton, 'The Content of Authoritarian Constitutions', in T Ginsburg \& A Simpser (eds), Constitutions in Authoritarian Regimes (2014) 141, 144.

32 Barros, above n 30, 317 (emphasis added).

${ }^{33}$ L Hilbink, 'Agents of Anti-Politics: Courts in Pinochet's Regime', in T Ginsburg \& T Moustafa (eds). Rule by Law: The Politics of Courts in Authoritarian Regimes (2008) 102, 102.

${ }^{34}$ In its first ruling the Constitutional Court declared Article 30, para. 3 of the project on organic constitutional law of the Tribunal Constitucional to be unconstitutional. Indeed, according to the Court, permitting the Tribunal to use secret documentation to convict individuals while prohibiting the defendant any knowledge of this evidence represented an evident violation of the due process of law (see Barros, above n 30, $270 \mathrm{ff}$.).

${ }^{35}$ Sentencia Rol. No. 33, D.O., 3 October 1985.
} 
[...] a contrary interpretation not only would injure the spirit of the constitution but, also, common sense which is the base of all logical interpretation, since it might amount to exposing the plebiscite itself to a judgment of legitimacy of grave prejudice for the normal development of the future institutional order. ${ }^{36}$

Besides this case, the Tribunal Constitucional also declared the constitutional illegitimacy of laws that restricted free political competition or that gave the opportunity for arbitrary intervention in the political process. Indeed, several important legislative acts were considered by the Constitutional Court to be in contrast with the rights and freedoms provided for in the 1980 Constitution, such as equality before the law, equal protection of the law, due process, freedom of association and political rights.

Thus, the Court was crucial in assuring that the plebiscite 'would be a fair contest and a valid expression of the popular will. ${ }^{37}$ Pinochet was defeated in the plebiscite, as $55 \%$ of voters did not grant him another term in office.

\subsection{The Case of Egypt: The Role of the Supreme Constitutional Court}

In order to understand the role played by the Supreme Constitutional Court (SCC) during Hosni Mubarak's authoritarian regime (which lasted from 1981 to 2011), one has to begin by considering that when Gamal Abd al-Nasser died in 1970, Egypt was experiencing serious economic difficulties. This situation had largely developed through the nationalisation of much of the private sector and the elimination of any significant check on executive power, which produced a mass exodus of private capital from the country. Therefore, the priority of Nasser's successor, Anwar Sadat, was to attract foreign investments. However, as pointed out by Tamir Moustafa, 'given the regime's history of nationalising the vast majority of the private sector, it was difficult to convince investors that their assets would be safe from state seizure or adverse legislation on entering the Egyptian market. ${ }^{38}$ For this reason, Sadat decided to create a Supreme

\footnotetext{
${ }^{36}$ I follow the translation by Barros, above n 30, 299.

${ }^{37}$ Barros, above n 30, 305.

${ }^{38}$ T Moustafa, The Struggle for Constitutional Power: Law, Politics and Economic Development in Egypt (2007) 4.
} 
Constitutional Court, ${ }^{39}$ which was set up in $1980 .{ }^{40}$ This Court was designed to effectively protect property rights so as to placate investors' concerns. ${ }^{41}$

Mubarak, who succeeded Sadat in 1981 following the latter's assassination, was in favour of this protective policy. At the beginning, the Supreme Constitutional Court focused its activity on safeguarding economic rights, thus fulfilling the expectations of Sadat and Mubarak. However, by 1985 the Court began to grant people not only economic rights, but also civil and political rights. In this way, the Court directly confronted the executive, which was opposed to political liberalisation. As Clark Lombardi put it:

[...] by the mid-1980s the SCC was demonstrating a willingness to check the executive when it seemed unambiguously to violate explicit constitutional limitations on executive power - even if their decision touched upon sensitive issues. The SCC confronted the executive as early as 1985, when it issued a starting ruling setting limits on the executive's emergency powers. ${ }^{42}$

Moreover, starting from the early 1990s, the Court, on the basis of an expansive reading of the 1971 Constitution, began to rely on international human rights conventions so as to guarantee an even more effective protection of fundamental rights and freedoms (freedom of the press, freedom of association, and so on) to Egyptian citizens. ${ }^{43}$

Thus, in the period from 1985 to the end of the 1990s, the Supreme Constitutional Court, which had been conceived as an ally of the executive, turned into a body that often constrained the authoritarian regime. In the early 2000s, however, Mubarak put an end to the Court's boldness by packing it with regime-friendly judges.

\footnotetext{
39 The Court was assigned three main functions: first, it could issue binding interpretations of legislative acts if different judicial bodies disagree about their interpretation; second, it could resolve conflicts of jurisdiction between different judicial bodies; third, it could carry out constitutional reviews of legislative acts.

40 The Court was already provided for in the 1971 Constitution, but it started its activity ten years later because the enabling legislation was issued only in 1979.

${ }^{41}$ Moustafa, above $\mathrm{n} 38,57 \mathrm{ff}$.

${ }^{42}$ C Lombardi, 'Egypt's Supreme Constitutional Court: Managing Constitutional Conflict in an Authoritarian, Aspirationally “Islamic” State' (2008) 3 J of Comp L 234, 243.

${ }^{43}$ Lombardi, above n 42, 244-5; Moustafa, above n 38, 167-9.
} 


\subsection{The Case of Mexico: The Role of the IFE and the Electoral Court}

Mexico was characterised for a very long time by a non-democratic regime. Indeed, the era of a single hegemonic party, the PRI (Institutional Revolutionary Party), lasted for 71 years - i.e., from 1929, when the precursor to the party was established, ${ }^{44}$ to 2000 , when Mexico experienced its first alternation regarding the presidency of the republic. During its power, the PRI occupied almost all government offices, both at federal and local levels, thus relegating the opposition to 'window dressing'.

The transition to democracy in Mexico was extremely gradual and took place mainly through electoral reforms. ${ }^{45}$ Indeed, since 1977 several important changes have been made in the field of electoral legislation and electoral institutions, which eventually brought about the 'cambio politico' (political change). ${ }^{46}$ As far as the electoral institutions are concerned, it should be noted that for many years both the organisation and the adjudication of the elections were in the hands of the federal government. It goes without saying that this situation allowed the PRI to commit all kinds of electoral misdeeds. The electoral reforms - most of which were introduced through amendments to the 1917 Mexican Constitution - gradually remedied these problems by guaranteeing a more autonomous and independent electoral process, as well as judicial oversight of the elections. Indeed, the electoral processes were organised and monitored by the IFE (Federal Electoral Institute), whose independence had been significantly increased. Moreover, an Electoral Court (Tribunal Electoral del Poder Judicial de la Federación) was in charge of adjudicating the elections, thus putting an end to the 'self-certification of elections'.

What it is important to point out is that, especially in a first phase, ${ }^{47}$ the

\footnotetext{
44 The National Revolutionary Party was established in 1929, was renamed Party of the Mexican Revolution in 1938 and finally was renamed PRI in 1946.

45 Even though some important reforms were also implemented in other branches of government, such as the judiciary. For example, it is important to mention the 1994 constitutional reform, which significantly expanded the powers of the Supreme Court by transforming it into a 'true constitutional tribunal' (B Magaloni, 'Enforcing the Autocratic Political Order and the Role of Courts: The Case of Mexico', in Ginsburg \& Moustafa (eds), above n 33, 180, 199).

${ }^{46}$ R Becerra, P Salazar \& J Woldenberg, La mecánica del cambio politico en México: Elecciones, partidos y reformas (2000).

${ }^{47}$ See the 1977 reform, which has been defined as 'desencadenadora' (that is, a 'chain-breaking reform'): J Woldenberg, El cambio politico en México (2007) $18<\mathrm{http} / / /$ www.trielectoralhidalgo.org.mx/pdf/cuaderno.pdf> [accessed 11 April 2014], which partially changed the electoral system and the system of electoral oversight.
} 
electoral reforms carried out by the PRI were aimed at increasing the legitimacy of the regime without decreasing its power over the country. ${ }^{48}$ The PRI's purpose, then, was to perpetuate its hegemonic rule. With the passing of time, however, these reforms ended up producing the opposite effect. From a closed and static party system, Mexico turned into a more open and inclusive one, thus reflecting the growing political diversity that was gradually characterising the country. ${ }^{49}$ This transition culminated in the year 2000, which represents a watershed in the history of Mexico. Indeed, the PRI lost the presidential elections, and Vicente Fox, candidate of the National Action Party (PAN), became president of the republic.

\section{Concluding Remarks}

First, it is important to stress that this paper was not aimed by any means at predicting the weakening or the fall of the Moroccan and Jordanian monarchies following the constitutional reforms introduced in these countries. Rather, its purpose was to show, on the basis of a comparative analysis with other past authoritarian regimes, that constitutionalism may one day lead to significant constraints on the non-democratic regimes of Mohammed VI and Abdullah II. Indeed, the cases of Chile, Egypt and Mexico have highlighted the paradox according to which the seeds of the limits to authoritarian power (and in some cases, even of the transition to democracy) can be found in the very constitution adopted during the authoritarian regime. Thus, surviving constitutionalism in Morocco and Jordan, which has served to appease public dissatisfaction in the short-term so as to ensure the regimes' stability and continuity, may boomerang in the medium- and long-term.

Two main objections can be raised against this assumption, but both can be overcome. First, one can argue that even in the past, the two monarchs strengthened democratic institutions and procedures, but their power was not threatened by these constitutional changes. In Morocco, for example, King Hassan II (Mohammed VI's father) adopted two constitutions during the 1990s (one in 1992 and one in 1996) in which some relevant democratic novelties were introduced (such as the Constitutional Council, the Economic and Social Council and stronger protection of fundamental rights), but he managed to

\footnotetext{
${ }^{48}$ See D Gómez Álvarez, 'Pròlogo', in C Astudillo \& L Córdova Vianello, Los árbitros de las elecciones estatales: Una radiografia de su arquitectura institucional (2010) XIX, XXIV-XXV.

${ }^{49}$ See L Córdova Vianello, 'La reforma electoral y el cambio político en México', in Reforma política y electoral en América latina 1978-2007 (2008) 653, 658.
} 
maintain power in his hands. This time, however, the novelties introduced in the 2011 Moroccan Constitution and in the amendments to the 1952 Jordanian Constitution are much greater compared to the past, and therefore the possibility that they will produce 'democratic effects' on the two countries is undoubtedly higher. Indeed, the new Moroccan Constitution established the duty of the king to appoint the head of government from the party that wins the most seats in the elections to the House of Representatives, declared the supremacy of international conventions over domestic legislation, introduced concrete constitutional review, strengthened judicial independence, and guaranteed a greater protection of fundamental rights. Similarly, Jordan set up a Constitutional Court, abolished the king's power indefinitely to postpone elections, established an independent electoral commission to supervise the electoral process, and introduced judicial oversight of the elections.

In both countries, interestingly enough, among the most relevant novelties introduced by the constitutional reforms, one finds those regarding constitutional review, as well as independent organisation and judicial oversight of the elections, which are precisely the 'constitutional tools' that led to the constraint of the authoritarian regimes in Chile, Egypt and Mexico.

A second objection that can be raised refers to the fact that a comparative analysis with Chile, Egypt and Mexico can be misleading since the latter are presidential or semi-presidential regimes, while Morocco and Jordan are monarchies. It is true that, as mentioned above, ${ }^{50}$ Arab monarchs enjoy a high degree of religious or tribal legitimacy, are often considered the effective guarantors of social and political stability, and tend not to 'dirty their hands' in everyday politics. This special 'status' is undoubtedly an extremely important guarantee in times of unrest, and tends to make kings less vulnerable compared to presidents. Having said that, however, the characteristics and the dynamics of authoritarian monarchies are often very similar to authoritarian presidential regimes. Indeed, in both forms of government, power is concentrated in the hands of a single person (or single party, as in the case of Mexico), political pluralism is non-existent or strongly limited, territorial decentralisation is extremely weak, and the protection of fundamental rights and freedoms is not sufficiently guaranteed. Given these similarities, one cannot exclude that what happened in Chile, Egypt and Mexico might one day happen also in Morocco and Jordan. Thus, constitutionalism can become a weapon against authoritarian regimes notwithstanding the form of government.

\footnotetext{
${ }^{50}$ See above at $\$ 2$.
} 
In the post-colonial era, several monarchies have been overthrown in the Arab world and in Muslim (albeit non-Arab) countries following coups d'état and revolutions. ${ }^{51}$ If the Moroccan and Jordanian monarchies collapse one day, it will likely be due to these kinds of dramatic events. However, the constitutional reforms carried out by Mohammed VI and Abdullah II should not be underestimated: so far surviving constitutionalism has contributed to the kingdoms' stability and continuity, but one day it may turn into an effective constraint of authoritarian power, thus contributing to the establishment of a more democratic form of government.

${ }^{51}$ Egypt (1952), Tunisia (1957), Iraq (1958), North Yemen (1962), Federation of South Arabia (1967), Libya (1969), Afghanistan (1973) and Iran (1979). 